\title{
KDM7A Gene
}

National Cancer Institute

\section{Source}

National Cancer Institute. KDM7A Gene. NCI Thesaurus. Code C158440.

This gene is involved in histone demethylation and brain development. 